\title{
Expression of epithelial-mesenchymal transition-related genes in prostate tumours
}

\author{
G. V. Gerashchenko ${ }^{1 *}$, O. S. Mankovska ${ }^{1 *}$, A. A. Dmitriev², L. V. Mevs ${ }^{1}$, E. E. Rosenberg ${ }^{1}$, \\ M. V. Pikul ${ }^{3}$, M. V. Marynychenko 3 , O. P. Gryzodub ${ }^{4}$, E. O. Stakhovsky ${ }^{3}$, V. I. Kashuba ${ }^{1}$ \\ ${ }^{1}$ Institute of Molecular Biology and Genetics, NAS of Ukraine \\ 150, Akademika Zabolotnoho Str., Kyiv, Ukraine, 03680 \\ ${ }^{2}$ Engelhardt Institute of Molecular Biology, Russian Academy of Sciences \\ 32, Vavilova Str., Moscow, Russian Federation, 119991 \\ ${ }^{3}$ National Cancer Institute \\ 33/43, Lomonosova Str., Kyiv, Ukraine, 03022 \\ ${ }^{4}$ State Institution «Institute of Urology of NAMS of Ukraine» \\ 9-a, Yu. Kotsubyns'koho Str., Kyiv, Ukraine, 04053 \\ g.v.gerashchenko@imbg.org.ua
}

\begin{abstract}
Aim. To detect expression of EMT-related genes in prostate tumor samples and analyze a possible correlation between the gene expression level and clinical characteristics of prostate cancer in different groups. Methods. Expression of 19 genes was analyzed in 37 frozen samples of prostate cancer tissues at different tumor stages and Gleason scores, 37 paired conventionally normal prostate tissues and 20 samples of prostate adenomas, using quantitative PCR. Results. We have found that nine genes were expressed differently in benign and malignant prostate tumors, namely $A R$ (isoform 1), AR (isoform 2), PTEN, VIM, MMP9, KRT18, PCA3, HOTAIR and SCHLAP1. When different tumor stages were compared, we could identify six differentially expressed genes: KRT18, MMP9, VIM, PCA3, HOTAIR and SCHLAP1; when samples of tumors with different Gleason score were compared, we found that eight genes were expressed differently: $A R$ (isoform 1), $C D H 1, K R T 18, M M P$, OCLN, PCA3, HOTAIR and SCHLAP1. The datahad a high level of heterogeneity potentially due to various molecular subtypes of prostate cancer, i.e. a luminal subtype with a high expression of $C D H 1, O C L N, A R(1$ isof), KRT18, NKX3-1 and PSA; the stem-like subtype with the high expression of mesenchymal markers $C D H 2, F N 1$ and VIM and low expression of the epithelial markers. It is noteworthy that lncRNAs were specifically expressed in these two molecular subtypes. Conclusions. EMT-related genes were differentially expressed in benign and malignant prostate tumors. High heterogeneity of expression levels, especially in adenocarcinoma groups, might suggest the existence of at least two different molecular subtypes, luminal and stem-like. Further experiments are necessary for specification of the molecular subtypes of prostate adenocarcinoma.
\end{abstract}

K e y w o r d s: prostate tumors, EMT, relative gene expression, molecular subtypes, lncRNA.

(C) 2017 G. V. Gerashchenko et al.; Published by the Institute of Molecular Biology and Genetics, NAS of Ukraine on behalf of Biopolymers and Cell. This is an Open Access article distributed under the terms of the Creative Commons Attribution License (http://creativecommons.org/licenses/by/4.0/), which permits unrestricted reuse, distribution, and reproduction in any medium, provided the original work is properly cited

* These authors contributed equally to this work 


\section{Introduction}

Prostate cancer is one of the most commonly diagnosed cancers among men in the world. It is highly heterogeneous and complicated cancer type, when taking into account a wide variety of multiple genetic and demographic factors that affect cell transformation, as well as the different origins of cancerous cells [1, 2]. One of the critical molecular process for tumor progression is epithelial-to-mesenchymal cell transition (EMT), i.e. when epithelial cells are losing their characteristics and acquiring properties of the mesenchymal cells $[3,4]$.

It is known already, that many genes are involved in the EMT. There are well characterized changes in gene expression pattern for both, epithelial and mesenchymal cells [5]. We have selected several such genes, to study their expression and to analyze whether such genes may serve as biomarkers and/or classifiers of various subtypes of prostate cancer. Well known tumor suppressor genes, that are involved in EMT in prostate cancer, are NKX3-1, $P T E N$ and $C D H 1$. Unaltered activity and expression of $N K X 3-1$ and PTEN are essential for a normal prostate functioning [6]. E-cadherin, encoded by the $C D H 1$ gene, is one of the main markers of epithelial cells. Loss of $\mathrm{CDH} 1$ expression has been implicated in progression and metastasizing [7]. Another protein, playing a critical role in maintaining the barrier properties of a tight junction in epithelial cells is occludin (OCLN gene). Occluding has anti-metastasizing [8].

The opposite function in prostate cancer show genes as, for example, N-cadherin, encoded by the $C D H 2$ gene, fibronectin ( $F N 1)$ and vimentin $(V I M)$. These proteins are is a markers of mesenchymal cells, and their expression corresponds to more aggressive tumor phenotype [9].

Metalloproteinases accompany the malignant cell transformation and metastasizing [5, 10]. In particular, $M M P 9$ expression is associated with invasiveness and metastatic properties, infiltration of the tumor supporting cells and angiogenesis. $M M P 2$ expression increased with growth of a TNM grade and angiogenesis.

The androgen receptor $(A R)$ and its isoforms are steroid receptor and function as transcription factors. There is a cross-talk between AR signaling and the EMT. It means that deviations in a structure and function of AR can induce the EMT upon tumor progression [11].

PSA is one of the most known prostate cancer markers, encoded by the prostate-specific gene kallikrein $3(K L K 3)$. PSA is a normal prostate antigen, but its expression is increasing dramatically in prostate carcinogenesis. Nevertheless, inflammation, infection, trauma and benign prostatic hyperplasia (BPH) are also the causes of the elevated level of serum PSA. Therefore, PSA-based screening for prostate cancer is plagued by false positives, resulting in a positive predictive value of only 25 to $40 \%$ [12].

KRT18 is expressed in normal prostate luminal cells. KRT18 was overexpressed in a number of epithelial human cancers [13, 14]. In certain cases this marker is used to assess the differentiation stage of tumor tissues. MKI67 encodes a nuclear protein Ki67, a marker of proliferation. The association with the clinical outcomes of prostate cancer was described for $\mathrm{Ki} 67$, together with another marker, MIB-1. [15]. 
Upon cancer initiation and progression the obvious differences between normal and tumor cell was detected not only for proliferation and differentiation, but for apoptosis as well. $C A S P 3$ gene encodes caspase 3 protein, which is the most studied of the effector caspases. Expression of CASP3 was increased upon tumor progression in breast and prostate carcinomas $[16,17]$. XIAP (X-linked inhibitor of apoptosis protein) is a member of an IAP protein family, which consists of eight different proteins that were originally described as inhibitors of apoptosis. Some of them can bind and neutralize caspases. In prostate cancer, levels of XIAP are significantly higher, than in prostatic intraepithelial neoplasia [18].

The EMT might be regulated by lncRNA regions [19-21]. There are the prostate specific $\operatorname{lncRNA}$ region, encoding $P C A 3$. Prostate cancer antigen 3 (PCA3) is highly expressed in prostate cancer tissues, compared to normal prostate $\mathrm{s}$ [19]. There are accumulating evidences, that PCA3 is also involved in AR signaling. High expression of the another gene, encoded by IncRNA region, HOTAIR, is associated with metastasizing and poor prognosis in many tumor types [20]. Yet another gene, encoded by lncRNA region, SCHLAP1, is overexpressed in prostate cancer. SCHLAP1 levels may predict poor patient outcomes, including metastasizing and cancer specific mortality [21].

In total, we selected 19 genes associated with the EMT and studied their expression in both, benign and malignant prostate tumors.

The aim of our study is:

To detect relative expression of EMT-related genes in prostate tumor samples and analyze a possible correlation between gene expression level and clinical characteristics of prostate cancer in different groups.

\section{Materials and Methods}

A collection of prostate tissues. Samples of cancer tissue and CNT (at an opposite side of tumor) were frozen in a liquid nitrogen immediately after surgical resection at the National Cancer Institute (Kyiv, Ukraine). Benign prostate tumors (prostate adenoma samples) were collected at the Institute of Urology (Kyiv, Ukraine) after radical prostatectomy and frozen, as described above. The samples were collected in accordance with the Declaration of Helsinki and the guidelines issued by the Ethic Committee of the Institute of Urology of National Academy of Medical Sciences of Ukraine and of the National Cancer Institute of National Academy of Sciences of Ukraine (NASU), and an Ethic Committee of the Institute of Molecular biology and genetics of NASU. Experimental studies were conducted on 37 prostate adenocarcinoma samples of different Gleason score and stages; 37 paired CNT samples; 21 samples of benign prostate tumors (adenomas). Tumor samples were characterized, according to an International System of Classification of Tumors, based on the tumor-node-metastasis (TNM) and the World Health Organization (WHO) criteria. Clinical and pathological characteristics of prostate cancer samples are presented on Table 1.

Total RNA isolation and cDNA synthesis. 50-70 mg of frozen prostate tissues were disrupted to powder in liquid nitrogen. Total RNA was extracted by TRI-reagent (SIGMA) according to the manufacturer's protocol. Total 
RNA concentration was analyzed by spectrophotometer (NanoDrop Technologies Inc. USA). The total RNA samples quality was determined in a $1 \%$ agarose gel by band intensity of $28 \mathrm{~S}$ and $18 \mathrm{~S}$ rRNA (28S/18S ratio). cDNA was synthesized from $1 \mathrm{mkg}$ of the total RNA previously treated with RNase free DNase I (Thermo Fisher Scientific, USA) using RevertAid H Minus M-MuLV Reverse Transcriptase (Thermo Fisher Scientific, USA) according to the manufacturer's protocol.
Quantitative PCR. Relative gene expression (RE) levels of 19 genes were detected by QPCR, using Maxima SYBR Green Master mix (Thermo Fisher Scientific, USA) on BioRad CFX96 Real-Time PCR Detection System (USA) under the following conditions: $95^{\circ} \mathrm{C}-$ 10 minutes, following 40 cycles of $95{ }^{\circ} \mathrm{C}-$ 15 seconds, $60{ }^{\circ} \mathrm{C}-30$ seconds, elongation $72{ }^{\circ} \mathrm{C}-30$ seconds. Primers for genes were selected from qPrimerDepot (https://primerdepot.nci.nih.gov/).

Table 1. Clinical and pathological characteristics (CPC) of prostate cancer samples.

\begin{tabular}{|r|c|c|c|c|c|r|c|c|c|c|c|}
\hline Sample N & Age & TNM & Stage & GL & PSA ng/ml & Sample N & Age & TNM & Stage & GL & PSA ng/ml \\
\hline $\mathbf{1}$ & 54 & T2cNxM0 & II & $<7$ & 27,3 & $\mathbf{2 0}$ & 52 & T2bN0M0 & III & 7 & 24,6 \\
$\mathbf{2}$ & 56 & T2cNxM0 & II & $<7$ & 25,2 & $\mathbf{2 1}$ & 60 & T3bN0M0 & III & $>7$ & 12,1 \\
$\mathbf{3}$ & 55 & T2pN0M0 & II & $<7$ & 5,0 & $\mathbf{2 2}$ & 53 & T2bNxM0 & II & $>7$ & 6,9 \\
$\mathbf{4}$ & 67 & T2cN0M0 & II & $<7$ & 29,1 & $\mathbf{2 3}$ & 63 & T3bNxM0 & III & $>7$ & 20,9 \\
$\mathbf{5}$ & 66 & T2bNxM0 & II & $<7$ & 6,5 & $\mathbf{2 4}$ & 56 & T3bN0M0 & III & $>7$ & 84,2 \\
$\mathbf{6}$ & 71 & T2bN0M0 & II & $<7$ & 12,8 & $\mathbf{2 5}$ & 48 & T3bNxM0 & III & $>7$ & 51,0 \\
$\mathbf{7}$ & 57 & T2aN0M0 & II & $<7$ & 9,3 & $\mathbf{2 6}$ & 65 & T2bNxM0 & II & $>7$ & 33,0 \\
$\mathbf{8}$ & 67 & T2aNxM0 & II & $<7$ & 18,6 & $\mathbf{2 7}$ & 61 & T2bNxM0 & III & $>7$ & 0,5 \\
$\mathbf{9}$ & 63 & T2aN0M0 & II & $<7$ & 13,3 & $\mathbf{2 8}$ & 76 & T3aN0M1 & IV & $>7$ & 37,8 \\
$\mathbf{1 0}$ & 54 & T2aN0M0 & II & $<7$ & 6,0 & $\mathbf{2 9}$ & 54 & T3bNxM0 & III & $>7$ & 106,0 \\
$\mathbf{1 1}$ & 74 & T3bNxM0 & III & $<7$ & 23,6 & $\mathbf{3 0}$ & 58 & T2cN1M0 & IV & $>7$ & 17,0 \\
$\mathbf{1 2}$ & 68 & T1cNxM0 & I & 7 & 8,2 & $\mathbf{3 1}$ & 58 & T3aN0M0 & III & $>7$ & 25,1 \\
$\mathbf{1 3}$ & 68 & T2cNxM0 & II & 7 & 19,3 & $\mathbf{3 2}$ & 63 & T2bN0M0 & II & $>7$ & 20,3 \\
$\mathbf{1 4}$ & 64 & T2cNxM0 & II & 7 & 19,8 & $\mathbf{3 3}$ & 62 & T2cN0M1 & IV & $>7$ & 22,6 \\
$\mathbf{1 5}$ & 77 & T2aNxM0 & II & 7 & 11,7 & $\mathbf{3 4}$ & 67 & T3bNxM0 & III & $>7$ & 16,0 \\
$\mathbf{1 6}$ & 69 & T2cNxM0 & II & 7 & 13,9 & $\mathbf{3 5}$ & 63 & T3bNxM0 & III & $>7$ & 86,3 \\
$\mathbf{1 7}$ & 54 & T2aNxM0 & II & 7 & 7,1 & $\mathbf{3 6}$ & 66 & T2cN1M0 & III & $>7$ & 2,3 \\
$\mathbf{1 8}$ & 62 & T2aNxM0 & II & 7 & 5,6 & $\mathbf{3 7}$ & 65 & T2cN0M0 & II & $>7$ & 9,7 \\
$\mathbf{1 9}$ & 69 & T2cN0M0 & II & 7 & 14,3 & & & & & & \\
\hline
\end{tabular}

Note: TNM - Classification of Malignant Tumors, based on the tumor-node-metastasis, GL - Gleason score, PSA prostate specific antigen concentration in blood. 
Four reference genes TBP, HPRT, ALASI and $T U B A 1 B$ were used for gene expression normalization [22]. Two main models for RE levels calculation were used. There were Livak method $2^{-\Delta \mathrm{Ct}}$ and $2^{-\Delta \Delta \mathrm{Ct}}$ methods - representing relative quantities and fold changes accordingly [23].

Statistical analysis. The KolmogorovSmirnov and Lilliefors tests were used for assessing normality of distribution. KruskalWallis test was used for determine differences in multiple comparison between experimental groups. Wilcoxon Matched Pairs test was performed for dependent sampling of RE prostate adenocarcinoma and paired conventional normal tissues tissues. The Benjamini-Hochberg procedure with false discovery rate 0,10 was used to correct $p$ value under multiple comparisons detection [24].

Dunn-Bonferoni post hoc test was used to determine RE differences between pairs of prostate samples groups. Spearman's rank correlation test was used to determine correlations between gene expression levels and CPC of prostate tumors, $\mathrm{RE}$ and correlations between the investigated genes.

\section{Results}

RE of 19 genes were assessed to monitor differences between prostate adenocarcinoma samples $(\mathrm{T})$, conventionally normal prostate tissues $(\mathrm{N})$ and benign prostate tumors (adenomas) (A) (Table 2A, 2B). According to a statistical analysis, RE of genes in an adenoma group did not show the Gaussian distribution; therefore, nonparametric statistical tests and methods were used.

We found 9 genes with statistically significant differences $(\mathrm{p}<0.05)$ in RE between 3 investigated groups by the Kruskal-Wallis test with FDR correction: $A R$ (1 isof), $A R$ (2 isof), PTEN, VIM, MMP9, KRT18, PCA3, HOTAIR and $S C H L A P 1$. Gene expression profiles in all groups are shown on Figure 1. We found that values were heterogeneous in each group, especially in a carcinoma group for the majority of the investigated genes.

Following Dunn-Bonferroni post hoc method for multiple comparisons, we found differences in RE for the 15 pairs of groups for these genes (Table 2B). Thus, RE of $A R$ (1 isof), $A R$ ( 2 isof) and PTEN are the highest in the adenoma group and are significantly decreased in the adenocarcinoma group for both $A R$ transcripts and PTEN $(\mathrm{p}=0,021, \mathrm{p}=0,047$, $\mathrm{p}=0,015$, respectively). Similar significant changes were observed for the adenoma group and normal prostate tissues for $A R$ (1 isof) and PTEN ( $\mathrm{p}=0,045 ; \mathrm{p}=0,047)$. RE of VIM was the highest also in adenomas and showed the significant differences, compared with group of normal prostate tissues $(p=0,007)$, whereas no differences with adenocarcinoma group were found. The opposite situation was observed in RE of MMP9, PCA3 and SCHLAP1 in adenomas. They showed the lowest levels, and this was significantly different, compared with RE in adenocarcinomas - $(\mathrm{p}=0,0001$, $\mathrm{p}=0,001, \mathrm{p}=0,013$, correspondingly) and in normal tissues - for MMP9 $(\mathrm{p}=0,015)$ and PCA3 $(\mathrm{p}=0,006)$. RE of KRT18 and HOTAIR demonstrated similar trend of changes. The highest levels of RE was observed in the adenocarcinoma group, and this was significantly different with both normal tissue groups ( $p=0,018, p=0,047$, correspondingly) and the adenoma group $(p=0,001, p=0,0001)$, which demonstrated the lowest RE. Only the 
G. V. Gerashchenko, O. S. Mankovska, A. A. Dmitriev et al.

Table 2. Descriptive statistics of the data on RE in the prostate adenocarcinoma (T), conventionally normal tissue (N) and adenoma (A) sample groups (2A) and RE differences between pairs of groups (2B)

$2 A$.

\begin{tabular}{|c|c|c|c|c|c|c|c|}
\hline Gene & Sample group & Median & Minimum & Maximum & 25 th percentile & 75th percentile & $\mathrm{p}<0,05^{*}$ \\
\hline \multirow{3}{*}{$A R$ (1 isof) } & $\mathrm{T}$ & 1,377 & 0,413 & 3,353 & 0,911 & 2,228 & \multirow{3}{*}{0,017} \\
\hline & $\mathrm{N}$ & 1,428 & 0,447 & 6,834 & 1,069 & 2,119 & \\
\hline & A & 2,129 & 0,879 & 4,936 & 1,623 & 2,672 & \\
\hline \multirow{3}{*}{$A R$ (2 isof) } & $\mathrm{T}$ & 0,020 & 0,000 & 0,069 & 0,012 & 0,033 & \multirow{3}{*}{0,031} \\
\hline & $\mathrm{N}$ & 0,022 & 0,000 & 0,083 & 0,015 & 0,028 & \\
\hline & A & 0,029 & 0,014 & 0,051 & 0,023 & 0,038 & \\
\hline \multirow{3}{*}{ CASP3 } & $\mathrm{T}$ & 0,318 & 0,040 & 0,869 & 0,170 & 0,419 & \\
\hline & $\mathrm{N}$ & 0,288 & 0,058 & 0,685 & 0,194 & 0,402 & \\
\hline & A & 0,303 & 0,152 & 1,088 & 0,207 & 0,587 & \\
\hline \multirow{3}{*}{$\mathrm{CDH} 1$} & $\mathrm{~T}$ & 3,237 & 0,053 & 10,097 & 1,572 & 4,676 & \\
\hline & $\mathrm{N}$ & 3,707 & 0,888 & 8,253 & 2,562 & 4,942 & \\
\hline & $\mathrm{A}$ & 2,752 & 0,004 & 8,941 & 2,001 & 3,661 & \\
\hline \multirow{3}{*}{$\mathrm{CDH} 2$} & $\mathrm{~T}$ & 0,103 & 0,001 & 1,361 & 0,056 & 0,146 & \\
\hline & $\mathrm{N}$ & 0,125 & 0,023 & 1,101 & 0,073 & 0,255 & \\
\hline & $\mathrm{A}$ & 0,083 & 0,020 & 0,482 & 0,060 & 0,178 & \\
\hline \multirow{3}{*}{ FN1 } & $\mathrm{T}$ & 4,840 & 1,401 & 41,496 & 3,557 & 8,230 & \\
\hline & $\mathrm{N}$ & 4,706 & 1,677 & 13,307 & 2,987 & 6,879 & \\
\hline & $\mathrm{A}$ & 4,051 & 1,779 & 8,593 & 3,017 & 5,234 & \\
\hline \multirow{3}{*}{ KRT18 } & $\mathrm{T}$ & 21,740 & 1,798 & 84,078 & 16,570 & 31,828 & \\
\hline & $\mathrm{N}$ & 15,868 & 4,798 & 46,191 & 9,987 & 19,905 & 0,0004 \\
\hline & A & 12,631 & 0,692 & 31,273 & 6,102 & 17,625 & \\
\hline \multirow{3}{*}{ МКI67 } & $\mathrm{T}$ & 0,127 & 0,014 & 1,220 & 0,049 & 0,212 & \\
\hline & $\mathrm{N}$ & 0,098 & 0,000 & 0,303 & 0,061 & 0,141 & \\
\hline & $\mathrm{A}$ & 0,102 & 0,039 & 0,267 & 0,068 & 0,152 & \\
\hline \multirow{3}{*}{ MMP2 } & $\mathrm{T}$ & 12,894 & 1,852 & 33,504 & 6,501 & 17,772 & \\
\hline & $\mathrm{N}$ & 9,950 & 1,855 & 29,948 & 6,825 & 12,982 & \\
\hline & $\mathrm{A}$ & 10,628 & 5,126 & 25,315 & 7,863 & 13,108 & \\
\hline \multirow{3}{*}{ МMP9 } & $\mathrm{T}$ & 0,918 & 0,028 & 27,489 & 0,345 & 2,466 & \\
\hline & $\mathrm{N}$ & 0,674 & 0,052 & 8,441 & 0,243 & 1,385 & 0,001 \\
\hline & A & 0,196 & 0,011 & 1,046 & 0,122 & 0,424 & \\
\hline \multirow{3}{*}{ NKX3-1 } & $\mathrm{T}$ & 0,314 & 0,028 & 6,543 & 0,110 & 0,571 & \\
\hline & $\mathrm{N}$ & 0,410 & 0,024 & 5,112 & 0,242 & 0,828 & \\
\hline & $\mathrm{A}$ & 0,344 & 0,032 & 1,640 & 0,139 & 0,543 & \\
\hline \multirow{3}{*}{$O C L N$} & $\mathrm{~T}$ & 0,568 & 0,059 & 3,790 & 0,336 & 1,214 & \\
\hline & $\mathrm{N}$ & 0,524 & 0,117 & 2,484 & 0,391 & 0,900 & \\
\hline & $\mathrm{A}$ & 0,396 & 0,227 & 1,574 & 0,332 & 0,593 & \\
\hline \multirow{3}{*}{$P S A$} & $\mathrm{~T}$ & 351,254 & 6,947 & 796,138 & 62,441 & 547,561 & \\
\hline & $\mathrm{N}$ & 355,608 & 4,584 & 1114,739 & 198,460 & 590,290 & \\
\hline & A & 323,470 & 1,203 & 768,968 & 78,968 & 520,212 & \\
\hline
\end{tabular}


Expression of epithelial-mesenchymal transition-related genes in prostate tumours

Table 2 A (breakover)

\begin{tabular}{|c|c|c|c|c|c|c|c|}
\hline Gene & Sample group & Median & Minimum & Maximum & 25 th percentile & 75th percentile & $\mathrm{p}<0,05^{*}$ \\
\hline \multirow{3}{*}{ PTEN } & $\mathrm{T}$ & 8,762 & 2,278 & 25,232 & 6,354 & 12,322 & \multirow{3}{*}{0,015} \\
\hline & $\mathrm{N}$ & 9,262 & 2,958 & 29,824 & 6,185 & 12,558 & \\
\hline & A & 16,989 & 5,875 & 90,619 & 8,964 & 22,065 & \\
\hline \multirow{3}{*}{$V I M$} & $\mathrm{~T}$ & 11,352 & 3,929 & 24,109 & 8,120 & 15,202 & \multirow{3}{*}{0,007} \\
\hline & $\mathrm{N}$ & 9,253 & 0,909 & 34,038 & 6,056 & 12,017 & \\
\hline & A & 12,947 & 7,836 & 31,417 & 10,163 & 15,474 & \\
\hline \multirow{3}{*}{$X I A P$} & $\mathrm{~T}$ & 0,349 & 0,078 & 0,995 & 0,215 & 0,479 & \\
\hline & $\mathrm{N}$ & 0,344 & 0,044 & 0,925 & 0,219 & 0,488 & \\
\hline & A & 0,301 & 0,182 & 0,896 & 0,235 & 0,386 & \\
\hline \multirow{3}{*}{$P C A 3^{\#}$} & $\mathrm{~T}$ & 0,647 & 0,007 & 56,165 & 0,074 & 19,017 & \multirow{3}{*}{0,001} \\
\hline & $\mathrm{N}$ & 0,318 & 0,000 & 27,228 & 0,088 & 1,970 & \\
\hline & A & 0,044 & 0,001 & 7,342 & 0,023 & 0,132 & \\
\hline \multirow{3}{*}{ HOTAIR ${ }^{\#}$} & $\mathrm{~T}$ & 0,015 & 0,000 & 0,079 & 0,004 & 0,037 & \multirow{3}{*}{0,0004} \\
\hline & $\mathrm{N}$ & 0,004 & 0,000 & 0,057 & 0,001 & 0,011 & \\
\hline & A & 0,001 & 0,000 & 0,015 & 0,000 & 0,003 & \\
\hline \multirow{3}{*}{$S C H L A P 1^{\#}$} & $\mathrm{~T}$ & 0,029 & 0,000 & 2,350 & 0,015 & 0,307 & \multirow{3}{*}{$\mathbf{0 , 0 1 7}$} \\
\hline & $\mathrm{N}$ & 0,032 & 0,000 & 1,148 & 0,013 & 0,079 & \\
\hline & A & 0,008 & 0,000 & 0,117 & 0,002 & 0,018 & \\
\hline
\end{tabular}

$2 B$.

\begin{tabular}{|l|c|r|}
\hline \multicolumn{1}{|c|}{ Genes } & $\begin{array}{c}\text { Pairs with } \\
\text { differences }\end{array}$ & p-value ** \\
\hline \multirow{2}{*}{ AR(1isof) } & T/A & $\mathbf{0 , 0 2 1}$ \\
& N/A & $\mathbf{0 , 0 4 5}$ \\
\hline AR (2isof) & T/A & $\mathbf{0 , 0 4 7}$ \\
\hline \multirow{2}{*}{ KRT18 } & T/A & $\mathbf{0 , 0 0 1}$ \\
& T/N & $\mathbf{0 , 0 1 8}$ \\
\hline \multirow{2}{*}{ MMP9 } & T/A & $\mathbf{0 , 0 0 0}$ \\
& N/A & $\mathbf{0 , 0 1 5}$ \\
\hline
\end{tabular}

\begin{tabular}{|l|c|r|}
\hline \multicolumn{1}{|c|}{ Genes } & $\begin{array}{c}\text { Pairs with } \\
\text { differences }\end{array}$ & p-value ** \\
\hline \multirow{2}{*}{ PTEN } & T/A & $\mathbf{0 , 0 1 5}$ \\
& N/A & $\mathbf{0 , 0 4 7}$ \\
\hline VIM & N/A & $\mathbf{0 , 0 0 7}$ \\
\hline \multirow{2}{*}{ PCA3 $^{\#}$} & T/A & $\mathbf{0 , 0 0 1}$ \\
\hline \multirow{2}{*}{ HOTAIR $^{\#}$} & N/A & $\mathbf{0 , 0 0 6}$ \\
\hline SCHLAPI $^{\#}$ & T/A & $\mathbf{0 , 0 0 0}$ \\
\hline
\end{tabular}

Notes: * Kruskal-Wallis test data significant with $\mathrm{FDR}=0,1$;

** - Dunn-Bonferroni post hoc method for multiple comparisons

$\#$ - IncRNA 

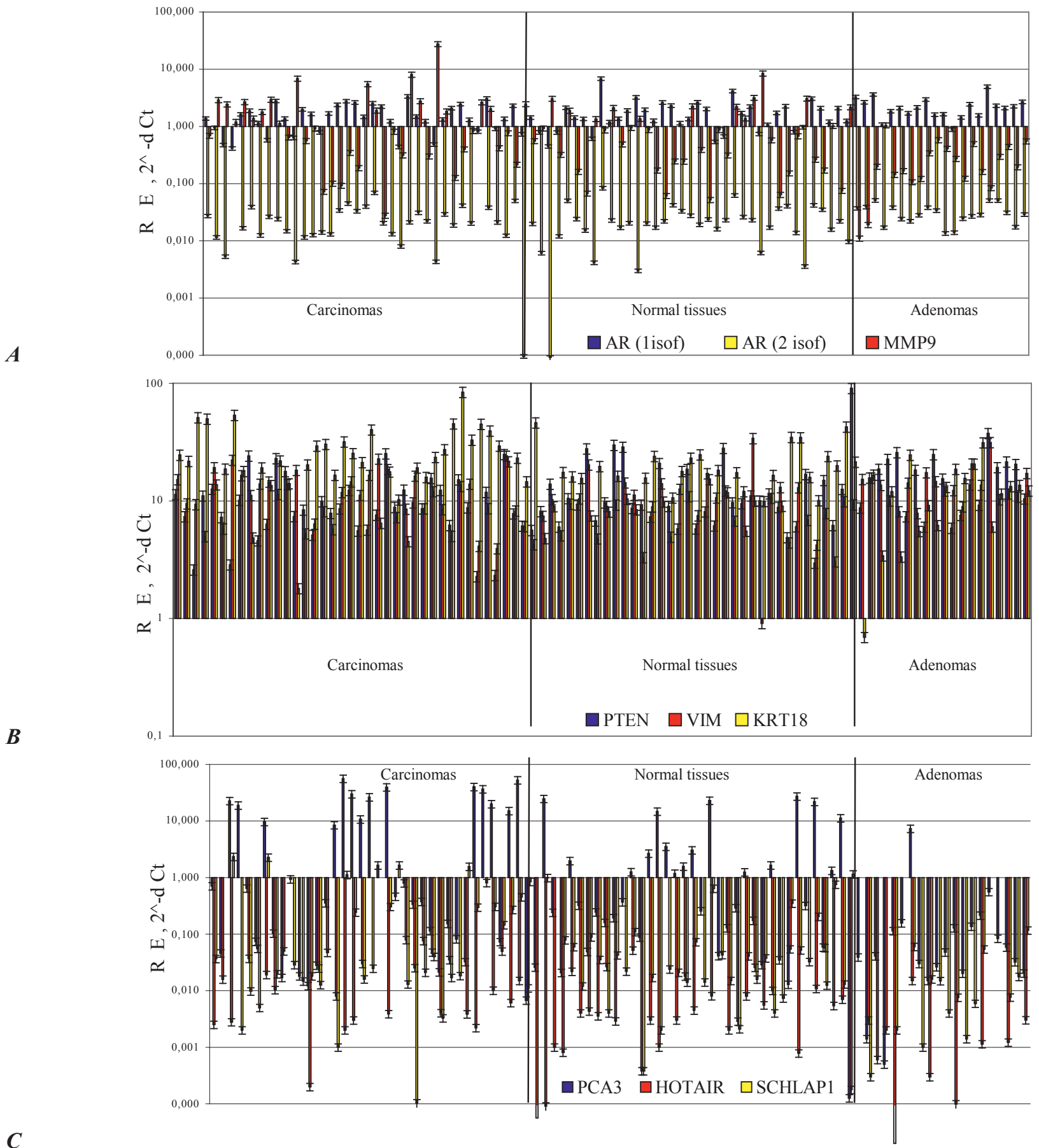

Fig. 1. RE profiles in prostate adenocarcinomas, conventionally normal tissues and adenomas $: A$ ) RE profile of $A R$ (1 isof), AR (2 isof) and MMP9 genes; B) RE profile of PTEN, VIM, KRT18; C) RE profile of PCA3, HOTAIR, SCHLAP1. 
KRT18 and HOTAIR genes showed RE differences between the adenocarcinoma and normal prostate tissue groups, when analyzed by the Dunn-Bonferroni post hoc method.

The other way to find the differences between adenocarcinoma and normal tissue groups is to compare paired tumor-normal tissue samples (from one patient). We have performed Wilcoxon Matched Pairs test with FDR correction $(\mathrm{FDR}=0,1)($ Table 3$) .6$ genes showed the statistically significant differences in RE between prostate adenocarcinoma samples and paired conventionally normal tissues: KRT18, MKI67, MMP2, MMP9, VIM, HOTAIR.

These differences may be dependent on the statistical analysis, i.e. on an algorithm of the method and its sensitivity. Further analysis is necessary, for sure

A stage of a cancer disease is one of the most important CPCs. We grouped all samples of prostate cancer and corresponding normal tissues into two groups: $1-2$ stages (22 samples) and 3-4 stages (15 samples). After analysis, we found 6 genes with statistically significant differences in RE in these experimental groups (Table 4A, 4B).

6 out of 19 genes demonstrated significant differences in RE. All these genes showed similar trends in previously analyzed three

Table 3. RE differences between prostate adenocarcinoma samples and paired normal tissues (dependent sampling)

\begin{tabular}{|c|c|l|c|}
\hline Gene & p-value \& & \multicolumn{1}{|c|}{ Gene } & p-value \& \\
\hline KRT18 & $\mathbf{0 , 0 0 0 4}$ & MMP9 & $\mathbf{0 , 0 1 3 6}$ \\
\hline MKI67 & $\mathbf{0 , 0 1 6 8}$ & VIM & $\mathbf{0 , 0 0 9 7}$ \\
\hline MMP2 & $\mathbf{0 , 0 1 0 6}$ & HOTAIR & $\mathbf{0 , 0 0 6 5}$ \\
\hline
\end{tabular}

Note: \& - Wilcoxon Matched Pairs test significant with $\mathrm{FDR}=0,1$ groups. Among these genes there were 3 coding genes (KRT18, MMP9 and VIM) and 3 genes, encoded by lncRNA regions ( $P C A 3$, HOTAIR, SCHLAP1). It was found 11 pairs with significant RE differences.

Almost all genes showed significant RE differences in the adenoma group, compared with the adenocarcinoma group or normal prostate tissue at various stages, when the Dunn-Bonferroni post hoc method was used. Surprisingly, no differences between the adenocarcinoma and the normal tissue groups was revealed, at the same stage.

Among CPC, a Gleason score is an important parameter for description of prostate cancer differentiation, aggressiveness and also for prognosis. Three grouping parameters of Gleason score were used to divide the prostate adenocarcinoma group $(\mathrm{T})$ and respective conventionally normal prostate tissues $(\mathrm{N})$ into 3 groups: Gleason score $<7(\mathrm{GL}<7)(11 \mathrm{sam}-$ ples), Gleason score $=7(\mathrm{GL}=7)(9$ samples $)$, Gleason score $>7$ (GL > 7) (17 samples). Moreover, we also used the adenomas group (A) for comparison.

In total, we had 7 sample groups for RE analysis (Table 5A and Table 5B). Ten of 19 genes showed the significant differences in $\mathrm{RE}$, according to the Kruskal-Wallis test. The Dunn-Bonferroni post hoc method for multiple comparisons has confirmed the significant differences only for 8 out of 10 genes. Noteworthy, the levels of RE of $\mathrm{CDHI}$ in prostate adenocarcinoma with different Gleason score showed a high grade of heterogeneity. The highest expression was observed in the adenocarcinoma group $(\mathrm{GL}=7)$, which had significant differences with the adenocarcinoma $(\mathrm{GL}>7)$ group (the lowest expression in carcinomas) 
G. V. Gerashchenko, O. S. Mankovska, A. A. Dmitriev et al.

Table 4. Descriptive statistics of the data on $\mathbf{R E}$ with significant differences in $\mathbf{T}, \mathbf{N}, \mathbf{A}$ sample groups at the various stages (st) (4A) and differences in $\mathrm{RE}$ between the pairs of prostate groups at different stages (4B).

$4 A$.

\begin{tabular}{|c|c|c|c|c|c|c|c|}
\hline Gene & Sample group & Median & Minimum & Maximum & 25 th percentile & 75th percentile & $\mathbf{p}<0,05^{*}$ \\
\hline \multirow{5}{*}{ KRT18 } & $\mathrm{T}(1-2 \mathrm{st})$ & 19,699 & 1,798 & 53,528 & 14,052 & 29,296 & \multirow{5}{*}{0,0014} \\
\hline & $\mathrm{T}(3-4 \mathrm{st})$ & 27,333 & 4,517 & 84,078 & 19,084 & 44,961 & \\
\hline & $N(1-2 \mathrm{st})$ & 15,612 & 4,798 & 23,940 & 9,817 & 17,485 & \\
\hline & $N(3-4 \mathrm{st})$ & 18,203 & 5,534 & 46,191 & 10,064 & 34,570 & \\
\hline & $\mathrm{A}$ & 12,631 & 0,692 & 31,273 & 6,102 & 17,625 & \\
\hline \multirow{5}{*}{ MMP9 } & $\mathrm{T}(1-2 \mathrm{st})$ & 1,020 & 0,072 & 6,867 & 0,215 & 2,677 & \multirow{5}{*}{$\mathbf{0 , 0 0 3 3}$} \\
\hline & $\mathrm{T}(3-4 \mathrm{st})$ & 0,833 & 0,028 & 27,489 & 0,399 & 2,466 & \\
\hline & $N(1-2 s t)$ & 0,565 & 0,061 & 2,257 & 0,170 & 1,351 & \\
\hline & $N(3-4 s t)$ & 0,864 & 0,052 & 8,441 & 0,263 & 3,042 & \\
\hline & A & 0,196 & 0,011 & 1,046 & 0,122 & 0,424 & \\
\hline \multirow{5}{*}{ VIM } & $\mathrm{T}(1-2 \mathrm{st})$ & 11,254 & 3,929 & 22,227 & 6,375 & 14,506 & \multirow{5}{*}{0,0164} \\
\hline & $\mathrm{T}(3-4 \mathrm{st})$ & 13,299 & 4,126 & 24,109 & 8,521 & 16,545 & \\
\hline & $N(1-2 s t)$ & 8,965 & 0,909 & 20,286 & 5,072 & 10,537 & \\
\hline & $N(3-4$ st $)$ & 10,613 & 4,212 & 34,038 & 6,859 & 12,958 & \\
\hline & A & 12,947 & 7,836 & 31,417 & 10,163 & 15,474 & \\
\hline \multirow{5}{*}{ PCA3 } & $\mathrm{T}(1-2 \mathrm{st})$ & 0,510 & 0,012 & 56,165 & 0,074 & 10,750 & \multirow{5}{*}{0,0043} \\
\hline & $\mathrm{T}(3-4 \mathrm{st})$ & 0,793 & 0,007 & 40,224 & 0,073 & 22,755 & \\
\hline & $N(1-2 s t)$ & 0,775 & 0,021 & 14,769 & 0,159 & 1,970 & \\
\hline & $N(3-4$ st $)$ & 0,256 & 0,000 & 27,228 & 0,041 & 22,031 & \\
\hline & A & 0,044 & 0,001 & 7,342 & 0,023 & 0,132 & \\
\hline \multirow{5}{*}{ HOTAIR } & $\mathrm{T}(1-2 \mathrm{st})$ & 0,013 & 0,000 & 0,076 & 0,000 & 0,035 & \multirow{5}{*}{0,0014} \\
\hline & $\mathrm{T}(3-4 \mathrm{st})$ & 0,004 & 0,000 & 0,079 & 0,002 & 0,025 & \\
\hline & $N(1-2 s t)$ & 0,003 & 0,000 & 0,051 & 0,001 & 0,008 & \\
\hline & $\mathrm{N}(3-4 \mathrm{st})$ & 0,003 & 0,000 & 0,057 & 0,001 & 0,011 & \\
\hline & A & 0,000 & 0,000 & 0,015 & 0,0001 & 0,001 & \\
\hline \multirow{5}{*}{ SCHLAP1 } & $\mathrm{T}(1-2 \mathrm{st})$ & 0,018 & 0,000 & 2,274 & 0,005 & 0,029 & \multirow{5}{*}{0,008} \\
\hline & $\mathrm{T}(3-4 \mathrm{st})$ & 0,297 & 0,000 & 2,350 & 0,013 & 0,847 & \\
\hline & $N(1-2 s t)$ & 0,019 & 0,000 & 0,110 & 0,004 & 0,042 & \\
\hline & $\mathrm{N}(3-4 \mathrm{st})$ & 0,038 & 0,000 & 1,148 & 0,014 & 0,350 & \\
\hline & A & 0,005 & 0,000 & 0,117 & 0,001 & 0,017 & \\
\hline
\end{tabular}


$4 B$.

\begin{tabular}{|l|l|l|}
\hline \multicolumn{1}{|c|}{ Genes } & \multicolumn{1}{c|}{ Pairs with differences } & \multicolumn{1}{c|}{ p-value ** } \\
\hline \multirow{2}{*}{ KRT18 } & $\mathrm{T}(3-4 \mathrm{st}) / \mathrm{A}$ & $\mathbf{0 , 0 0 1 5}$ \\
& $\mathrm{T}(3-4 \mathrm{st}) / \mathrm{N}(1-2 \mathrm{st})$ & $\mathbf{0 , 0 2 6 9}$ \\
\hline \multirow{2}{*}{$\boldsymbol{M} \boldsymbol{M P 9}$} & $\mathrm{T}(1-2 \mathrm{st}) / \mathrm{A}$ & $\mathbf{0 , 0 1 1 5}$ \\
& $\mathrm{T}(3-4 \mathrm{st}) / \mathrm{A}$ & $\mathbf{0 , 0 0 5 6}$ \\
\hline $\boldsymbol{V I M}$ & $\mathrm{N}(1-2 \mathrm{st}) / \mathrm{A}$ & $\mathbf{0 , 0 1 2}$ \\
\hline
\end{tabular}

\begin{tabular}{|l|l|l|}
\hline \multicolumn{1}{|c|}{ Genes } & \multicolumn{1}{|c|}{ Pairs with differences } & p-value ** \\
\hline \multirow{3}{*}{$\boldsymbol{P C A 3}$} & $\mathrm{T}(1-2 \mathrm{st}) / \mathrm{A}$ & $\mathbf{0 , 0 2 6 5}$ \\
& $\mathrm{T}(3-4 \mathrm{st}) / \mathrm{A}$ & $\mathbf{0 , 0 1 3 4}$ \\
& $\mathrm{N}(1-2 \mathrm{st}) / \mathrm{A}$ & $\mathbf{0 , 0 1 2 3}$ \\
\hline \multirow{2}{*}{ HOTAIR } & $\mathrm{T}(1-2 \mathrm{st}) / \mathrm{A}$ & $\mathbf{0 , 0 0 0 9}$ \\
& $\mathrm{T}(3-4 \mathrm{st}) / \mathrm{A}$ & $\mathbf{0 , 0 1 6 4}$ \\
\hline SCHLAP1 & $\mathrm{T}(3-4 \mathrm{st}) / \mathrm{A}$ & $\mathbf{0 , 0 0 5 2}$ \\
\hline
\end{tabular}

Notes: * Kruskal-Wallis significant with $\mathrm{FDR}=0,1$;

** - Dunn-Bonferroni post hoc method for multiple comparisons

$(\mathrm{p}=0,041)$. These differences were indistinguishable in the total cancer group. The directions of the RE changes in the normal tissue group was similar to the adenocarcinoma group. However, there were no statistically significant differences in comparison with the adenocarcinoma or with the adenoma group. RE levels of $A R$ ( 1 isof) changed similarly in the adenocarcinoma and the normal tissue groups. The significant changes were observed only between the adenocarcinoma $(\mathrm{GL}<7)$ and the adenomas groups $(p=0,028$. RE of $O C L N$ in the adenocarcinoma group RE with $\mathrm{GL}=7$ gene expression level had maximal value whereas adenoma group and adenocarcinoma group with GL $<7$ had minimal values and statistically significant differences with adenocarcinoma $\mathrm{GL}=7(\mathrm{p}=0,033, \mathrm{p}=0,049$ correspondently). A similar pattern of changes in RE was observed for the MMP9 and HOTAIR genes. The lowest values of RE were registered in the adenoma group; the differences were statically significant with the adenocarcinoma groups, where the highest expression of these genes were observed (MMP 9 $\mathrm{p}=0,0001, \mathrm{p}=0,043$, HOTAIR $\mathrm{p}=0,0033$, $\mathrm{p}=0,005$, respectively). KRT18 and SCHLAP1 were expressed at the highest levels in the adenocarcinoma group GL $>7$, and this differs significantly in comparison with the adenoma group ( $\mathrm{p}=0,018, \mathrm{p}=0,024$ correspondently).

Significant RE changes showed PCA3, when the adenoma group and the adenocarcinoma group GL $=7$ (and normal tissues group $\mathrm{GL}=7$ as well) were compared $(\mathrm{p}=0,027$, $\mathrm{p}=0,023$, respectively).

Although the Kruskal-Wallis test showed differences of RE levels between 7 groups for the CASP3 and XIAP genes, another paired test, namely the multiple comparisons DunnBonferroni post hoc method, did not confirm this data.

We would like to draw attention again to the fact that RE values for almost all genes in groups of conventionally normal tissues with different Gleason score had the same directions of expression change as the coincident adenocarcinomas groups, although the DunnBonferroni post hoc method did not show any significant differences. Probably, these alterations are the result of a cancer-normal tissue cross-talk in organism. 
G. V. Gerashchenko, O. S. Mankovska, A. A. Dmitriev et al.

Table 5. Descriptive statistics of the data on $\mathbf{R E}$ with significant differences in the $\mathbf{T}, \mathbf{N}$, A sample groups with the various Gleason score (GL<7, GL=7, GL>7) (5A) and $R E$ differences between pairs with different GL (5B)

$5 A$.

\begin{tabular}{|c|c|c|c|c|c|c|c|}
\hline Gene & Group & Median & Minimum & Maximum & 25 th percentile & 75th percentile & p-value * \\
\hline \multirow{7}{*}{$A R$ (1 isof) } & $\mathrm{T}$ GL $<7$ & 1,148 & 0,413 & 2,789 & 0,574 & 1,626 & \multirow{7}{*}{0,008} \\
\hline & $\mathrm{T} \mathrm{GL}=7$ & 1,992 & 0,787 & 2,765 & 1,661 & 2,539 & \\
\hline & $\mathrm{T}$ GL $>7$ & 1,323 & 0,440 & 3,353 & 0,911 & 2,228 & \\
\hline & N GL $<7$ & 1,357 & 0,447 & 6,834 & 0,783 & 1,430 & \\
\hline & $\mathrm{N} \mathrm{GL}=7$ & 1,961 & 1,145 & 3,227 & 1,354 & 2,629 & \\
\hline & $\mathrm{N} \mathrm{GL}>7$ & 1,720 & 0,537 & 4,153 & 0,967 & 2,098 & \\
\hline & $\mathrm{A}$ & 2,129 & 0,879 & 4,936 & 1,623 & 2,672 & \\
\hline \multirow{7}{*}{ CASP3 } & $\mathrm{T}$ GL $<7$ & 0,249 & 0,040 & 0,532 & 0,121 & 0,352 & \multirow{7}{*}{0,046} \\
\hline & $\mathrm{T} \mathrm{GL}=7$ & 0,414 & 0,170 & 0,579 & 0,365 & 0,450 & \\
\hline & $\mathrm{T}$ GL $>7$ & 0,290 & 0,074 & 0,869 & 0,148 & 0,394 & \\
\hline & N GL $<7$ & 0,265 & 0,075 & 0,647 & 0,166 & 0,310 & \\
\hline & $\mathrm{N} \mathrm{GL}=7$ & 0,399 & 0,294 & 0,572 & 0,334 & 0,486 & \\
\hline & $\mathrm{N} \mathrm{GL}>7$ & 0,234 & 0,058 & 0,685 & 0,149 & 0,320 & \\
\hline & A & 0,303 & 0,152 & 1,088 & 0,207 & 0,587 & \\
\hline \multirow{7}{*}{$\mathrm{CDH} 1$} & $\mathrm{~T}$ GL $<7$ & 3,035 & 0,896 & 8,601 & 1,521 & 3,954 & \multirow{7}{*}{0,010} \\
\hline & $\mathrm{T}$ GL $=7$ & 5,301 & 0,053 & 10,097 & 5,062 & 5,934 & \\
\hline & $\mathrm{T}$ GL $>7$ & 2,815 & 0,161 & 7,247 & 1,462 & 3,764 & \\
\hline & N GL $<7$ & 3,707 & 1,858 & 5,466 & 2,864 & 4,531 & \\
\hline & $\mathrm{N} \mathrm{GL}=7$ & 4,942 & 2,562 & 5,705 & 3,519 & 5,118 & \\
\hline & $\mathrm{N} \mathrm{GL}>7$ & 2,931 & 0,888 & 8,253 & 1,935 & 4,724 & \\
\hline & A & 2,752 & 0,004 & 8,941 & 2,001 & 3,661 & \\
\hline \multirow{7}{*}{ KRT18 } & $\mathrm{T}$ GL $<7$ & 19,122 & 4,854 & 53,528 & 13,718 & 49,804 & \multirow{7}{*}{0,012} \\
\hline & $\mathrm{T}$ GL $=7$ & 21,912 & 1,798 & 31,828 & 16,570 & 29,296 & \\
\hline & T GL $>7$ & 23,485 & 4,517 & 84,078 & 17,656 & 39,360 & \\
\hline & N GL $<7$ & 15,571 & 4,798 & 46,191 & 8,058 & 19,663 & \\
\hline & $\mathrm{N} \mathrm{GL}=7$ & 15,652 & 8,424 & 23,940 & 10,366 & 17,847 & \\
\hline & N GL>7 & 16,505 & 5,534 & 42,552 & 10,064 & 23,924 & \\
\hline & A & 12,631 & 0,692 & 31,273 & 6,102 & 17,625 & \\
\hline \multirow{7}{*}{ ММР9 } & $\mathrm{T}$ GL $<7$ & 1,795 & 0,642 & 6,867 & 1,122 & 2,897 & \multirow{7}{*}{0,001} \\
\hline & $\mathrm{T}$ GL=7 & 0,345 & 0,072 & 5,503 & 0,100 & 0,918 & \\
\hline & $\mathrm{T}$ GL $>7$ & 0,810 & 0,028 & 27,489 & 0,313 & 2,466 & \\
\hline & $\mathrm{N} \mathrm{GL}<7$ & 0,855 & 0,067 & 3,042 & 0,319 & 1,891 & \\
\hline & $\mathrm{N} \mathrm{GL}=7$ & 0,389 & 0,061 & 2,257 & 0,243 & 0,946 & \\
\hline & $\mathrm{N} \mathrm{GL}>7$ & 0,674 & 0,052 & 8,441 & 0,170 & 2,168 & \\
\hline & A & 0,196 & 0,011 & 1,046 & 0,122 & 0,424 & \\
\hline
\end{tabular}


Expression of epithelial-mesenchymal transition-related genes in prostate tumours

Table 5 A (breakover)

\begin{tabular}{|c|c|c|c|c|c|c|c|}
\hline Gene & Group & Median & Minimum & Maximum & 25 th percentile & 75th percentile & p-value * \\
\hline \multirow{7}{*}{ OCLN } & $\mathrm{T} \mathrm{GL}<7$ & 0,361 & 0,137 & 1,431 & 0,205 & 0,571 & \multirow{7}{*}{0,007} \\
\hline & $\mathrm{T} \mathrm{GL}=7$ & 1,080 & 0,525 & 3,790 & 0,649 & 1,846 & \\
\hline & $\mathrm{T}$ GL $>7$ & 0,565 & 0,059 & 3,491 & 0,318 & 1,157 & \\
\hline & $\mathrm{N} \mathrm{GL}<7$ & 0,411 & 0,248 & 0,893 & 0,310 & 0,478 & \\
\hline & $\mathrm{N} \mathrm{GL}=7$ & 0,636 & 0,512 & 1,376 & 0,537 & 0,949 & \\
\hline & $\mathrm{N} \mathrm{GL}>7$ & 0,565 & 0,117 & 2,484 & 0,391 & 1,061 & \\
\hline & A & 0,396 & 0,227 & 1,574 & 0,332 & 0,593 & \\
\hline \multirow{7}{*}{$X I A P$} & T GL $<7$ & 0,299 & 0,078 & 0,570 & 0,191 & 0,400 & \multirow{7}{*}{$\mathbf{0 , 0 1 9}$} \\
\hline & $\mathrm{T} \mathrm{GL}=7$ & 0,479 & 0,330 & 0,995 & 0,349 & 0,623 & \\
\hline & $\mathrm{T}$ GL $>7$ & 0,332 & 0,088 & 0,633 & 0,164 & 0,407 & \\
\hline & $\mathrm{N} \mathrm{GL}<7$ & 0,261 & 0,060 & 0,925 & 0,191 & 0,392 & \\
\hline & $\mathrm{N} \mathrm{GL}=7$ & 0,522 & 0,251 & 0,677 & 0,420 & 0,597 & \\
\hline & $\mathrm{N} \mathrm{GL}>7$ & 0,287 & 0,044 & 0,568 & 0,160 & 0,459 & \\
\hline & A & 0,301 & 0,182 & 0,896 & 0,235 & 0,386 & \\
\hline \multirow{7}{*}{$P C A 3$} & T GL $<7$ & 0,647 & 0,017 & 22,755 & 0,046 & 9,739 & \multirow{7}{*}{0,006} \\
\hline & $\mathrm{T} \mathrm{GL}=7$ & 8,480 & 0,012 & 56,165 & 0,355 & 26,476 & \\
\hline & $\mathrm{T}$ GL $>7$ & 0,374 & 0,007 & 52,746 & 0,081 & 19,972 & \\
\hline & $\mathrm{N} \mathrm{GL}<7$ & 0,240 & 0,021 & 24,781 & 0,049 & 0,369 & \\
\hline & $\mathrm{N} \mathrm{GL}=7$ & 1,574 & 0,088 & 14,769 & 1,182 & 3,060 & \\
\hline & $\mathrm{N} \mathrm{GL}>7$ & 0,289 & 0,000 & 27,228 & 0,041 & 1,649 & \\
\hline & A & 0,044 & 0,001 & 7,342 & 0,023 & 0,132 & \\
\hline \multirow{7}{*}{ HOTAIR } & $\mathrm{T}$ GL $<7$ & 0,017 & 0,003 & 0,056 & 0,007 & 0,043 & \multirow{7}{*}{0,004} \\
\hline & $\mathrm{T}$ GL $=7$ & 0,008 & 0,000 & 0,047 & 0,002 & 0,030 & \\
\hline & $\mathrm{T}$ GL $>7$ & 0,013 & 0,002 & 0,079 & 0,004 & 0,048 & \\
\hline & $\mathrm{N} \mathrm{GL}<7$ & 0,003 & 0,0004 & 0,027 & 0,001 & 0,004 & \\
\hline & $\mathrm{N} \mathrm{GL}=7$ & 0,003 & 0,0003 & 0,051 & 0,001 & 0,018 & \\
\hline & $\mathrm{N} \mathrm{GL}>7$ & 0,008 & 0,0004 & 0,057 & 0,003 & 0,011 & \\
\hline & A & 0,001 & 0,0002 & 0,015 & 0,000 & 0,003 & \\
\hline \multirow{7}{*}{ SCHLAP1 } & $\mathrm{T}$ GL $<7$ & 0,020 & 0,002 & 2,350 & 0,010 & 0,037 & \multirow{7}{*}{0,052} \\
\hline & $\mathrm{T}$ GL $=7$ & 0,018 & 0,001 & 1,120 & 0,013 & 0,242 & \\
\hline & T GL $>7$ & 0,270 & 0,000 & 1,651 & 0,018 & 0,452 & \\
\hline & $\mathrm{N} \mathrm{GL}<7$ & 0,042 & 0,004 & 0,989 & 0,022 & 0,079 & \\
\hline & $\mathrm{N} \mathrm{GL}=7$ & 0,017 & 0,0003 & 0,110 & 0,014 & 0,024 & \\
\hline & $N$ GL $>7$ & 0,038 & 0,002 & 1,148 & 0,013 & 0,204 & \\
\hline & A & 0,008 & 0,0003 & 0,117 & 0,002 & 0,040 & \\
\hline
\end{tabular}


$5 \boldsymbol{B}$. the $\mathrm{CDH} 2$ correlated with the Gleason score

\begin{tabular}{|c|c|c|}
\hline Genes (7 groups) & Groups pairs with differences & p-value $* *$ \\
\hline$A R$ (1isof) & $\mathrm{T} \mathrm{GL}<7 / \mathrm{A}$ & 0,028 \\
\hline CASP3 & no & \\
\hline $\mathrm{CDH} 1$ & $\mathrm{~T} \mathrm{GL}=7 / \mathrm{T} \mathrm{GL}>7$ & 0,041 \\
\hline KRT18 & $\mathrm{T} \mathrm{GL}>7 / \mathrm{A}$ & 0,018 \\
\hline MMP9 & $\begin{array}{l}\text { T GL }<7 / A \\
T \text { GL }>7 / A\end{array}$ & $\begin{array}{l}0,000 \\
0,043\end{array}$ \\
\hline OCLN & $\begin{array}{l}\mathrm{T} \mathrm{GL}=7 / \mathrm{A} \\
\mathrm{T} \mathrm{GL}<7 / \mathrm{T} \mathrm{GL}=7\end{array}$ & $\begin{array}{l}0,033 \\
0,049\end{array}$ \\
\hline$X I A P$ & no & \\
\hline PCA3 & $\begin{array}{l}T \text { GL }=7 / \mathrm{A} \\
N \text { GL }=7 / \mathrm{A}\end{array}$ & $\begin{array}{l}0,027 \\
0,021\end{array}$ \\
\hline HOTAIR & $\begin{array}{l}\mathrm{T} \mathrm{GL}<7 / \mathrm{A} \\
\mathrm{T} \mathrm{GL}>7 / \mathrm{A}\end{array}$ & $\begin{array}{l}0,033 \\
0,005\end{array}$ \\
\hline SCHLAP1 & $\mathrm{T}>7 / \mathrm{A}$ & 0,024 \\
\hline
\end{tabular}

Notes: * - Kruskal-Wallis significant with $\mathrm{FDR}=0,1$;

** - Dunn-Bonferroni post hoc method for multiple comparisons

When a $2^{\wedge}$-ddCt model was used to calculate $\mathrm{RE}$ in adenocarcinomas groups $\left(2^{\wedge}-\mathrm{dCt}\right.$ gene expression in each tumor sample was normalized to the paired normal tissue sample), no differences between the groups of adenocarcinoma and normal prostate tissue were shown for all of 19 genes. This result confirms our assumption about the cross-talk between tumors and normal tissue. Importantly, the $2^{\wedge}$-ddCt model is used to characterize only a range of the fold changes, but not thequantity of the mRNA of a certain gene.

Correlations between clinical and pathological characteristics and RE levels

The Spearman's rank correlation $\left(\mathrm{r}^{\mathrm{s}}\right)$ test produced a number of correlations between CPC (Gleason score, Age and PSA level) and the gene expression (Table 6 A). Thus, only RE of $\left(\mathrm{r}^{\mathrm{s}}=0,338, \mathrm{p}<0,05\right) . \mathrm{RE}$ of the SCHLAP1 correlated with the age and the PSA levels. PSA level was shown positive correlation $\left(\mathrm{r}^{\mathrm{s}}=0,436, \mathrm{p}<0,05\right)$, but Age group had reverse correlation with SCHLAPI RE $\left(\mathrm{r}^{\mathrm{s}}=-0,376, \mathrm{p}<0,05\right)$. The greatest number of correlations with RE was obtained for the Stage characteristic. There were six negative correlation of Stage with $C D H 1\left(\mathrm{r}^{\mathrm{s}}=-0,385\right.$, $\mathrm{p}<0,05), A R$ ( 1 isof), $A R$ ( 2 isof) ( $\mathrm{r}^{\mathrm{s}}=-0,381$, $\mathrm{r}^{\mathrm{s}}=-0,390$, accordingly $\left.\mathrm{p}<0,05\right), O C L N$ $\left(\mathrm{r}^{\mathrm{s}}=-0,360, \mathrm{p}<0,05\right), N K X 3-1\left(\mathrm{r}^{\mathrm{s}}=-0,353\right.$, $\mathrm{p}<0,05)$ and $X I A P\left(\mathrm{r}^{\mathrm{s}}=-0,352, \mathrm{p}<0,05\right)$.

Correlations between gene RE levels.

Correlation indexes between investigated genes (Table 6B) had more strong significance compared to CPC. The strongest indexes $\left(\mathrm{r}^{\mathrm{s}}|0,603-0,817|\right)$ with very high significance $(\mathrm{p}<0,0001)$ had 10 correlations. The highest value $\mathrm{r}^{\mathrm{s}}=0,817$ was for $N K X 3-1$ with $C D H 1$, $\mathrm{r}^{\mathrm{s}}=0,754$ had $C A S P 3$ with XIAP, and the highest inverse $\mathrm{r}^{\mathrm{s}}=-0,724$ had KRT18 with FN1. The greatest number of maximal correlations was for $O C L N$ (3 ones) with $A R$ (1 isof), NKX3-1, XIAP.

Moreover, we revealed 44 correlations between investigated genes $\left(\mathrm{r}^{\mathrm{s}}|0,402-0,652|\right)$ with significance $\mathrm{p}<0,01$ and 23 correlations $\left(\mathrm{r}^{\mathrm{s}}|0,338-0,422|\right)$ with significance $\mathrm{p}<0,05$. Large quantity of correlations between genes testify to close interrelation of molecular networks and carcinogenic processes, in which investigated genes participate.

\section{Discussion}

The EMT is an important process in carcinogenesis. It is known that increase in expression 
Expression of epithelial-mesenchymal transition-related genes in prostate tumours

Table 6. Spearman Rank Order Correlations ( $\left.\mathbf{r}^{\mathrm{s}}\right)$ of CPC with genes RE (6A) and between gene RE $\mathbf{r}^{\mathrm{s}}(6 \mathrm{~B})$

$6 A$.

\begin{tabular}{|l|r|r|r|r|r|r|r|r|r|}
\hline \multicolumn{1}{|c|}{ CPC } & \multicolumn{1}{c|}{ CDH1 } & \multicolumn{1}{c|}{ CDH2 } & \multicolumn{1}{c|}{ AR (1 isof) } & \multicolumn{1}{c|}{ AR (2 isof) } & \multicolumn{1}{c|}{ FN1 } & \multicolumn{1}{c|}{ VIM } & \multicolumn{1}{c|}{ OCLN } & \multicolumn{1}{c|}{ MMP2 } & \multicolumn{1}{c|}{ MMP9 } \\
\hline GL & $-0,171$ & 0,338 & 0,023 & 0,033 & 0,072 & $-0,076$ & 0,127 & $-0,057$ & $-0,135$ \\
Stage & $-0,385$ & 0,181 & $-0,381$ & $-0,390$ & 0,184 & 0,247 & $-0,360$ & 0,151 & 0,140 \\
PSA ng/ml & $-0,233$ & $-0,026$ & $-0,147$ & $-0,097$ & 0,065 & 0,087 & $-0,011$ & 0,080 & $-0,069$ \\
Age & $-0,001$ & 0,066 & $-0,154$ & $-0,069$ & 0,213 & $-0,224$ & $-0,071$ & $-0,058$ & $-0,029$ \\
\hline
\end{tabular}

\begin{tabular}{|l|r|r|r|r|r|r|r|r|r|r|}
\hline \multicolumn{1}{|c|}{ CPC } & \multicolumn{1}{|c|}{ NKX3-1 } & \multicolumn{1}{c|}{ PCA3 } & \multicolumn{1}{c|}{ PSA } & \multicolumn{1}{c|}{ KRT18 } & MKI67 & CASP3 & XIAP & PTEN & HOTAIR & SCHLAPI \\
\hline GL & $-0,052$ & 0,013 & 0,055 & 0,039 & $-0,016$ & 0,049 & 0,026 & 0,102 & 0,101 & 0,189 \\
Stage & $-0,353$ & $-0,128$ & $-0,305$ & $-0,052$ & $-0,276$ & $-0,126$ & $-0,352$ & 0,092 & 0,223 & $-0,006$ \\
PSA ng/ml & $-0,263$ & 0,127 & 0,072 & 0,107 & 0,029 & $-0,046$ & $-0,046$ & $-0,270$ & 0,003 & 0,436 \\
Age & 0,085 & $-0,151$ & $-0,300$ & $-0,208$ & 0,053 & 0,145 & 0,154 & $-0,007$ & 0,177 & $-0,376$ \\
\hline
\end{tabular}

$6 B$.

\begin{tabular}{|c|c|c|c|c|c|c|c|c|c|}
\hline Genes & $\mathrm{CDH1}$ & $\mathrm{CDH} 2$ & $A R$ (1 isof) & $A R(2$ isof $)$ & $F N 1$ & $V I M$ & $O C L N$ & $M M P 2$ & $M M P 9$ \\
\hline $\mathrm{CDH1}$ & 1,000 & & & & & & & & \\
\hline $\mathrm{CDH} 2$ & 0,027 & 1,000 & & & & & & & \\
\hline$A R$ (1 isof) & 0,439 & 0,272 & 1,000 & & & & & & \\
\hline$A R$ (2 isof) & 0,374 & 0,155 & 0,665 & 1,000 & & & & & \\
\hline FN1 & $-0,271$ & 0,447 & 0,069 & 0,099 & 1,000 & & & & \\
\hline VIM & $-0,422$ & $-0,033$ & $-0,235$ & $-0,444$ & 0,214 & 1,000 & & & \\
\hline OCLN & 0,585 & 0,057 & 0,609 & 0,523 & $-0,077$ & $-0,243$ & 1,000 & & \\
\hline$M M P 2$ & $-0,429$ & 0,226 & $-0,053$ & $-0,185$ & 0,298 & 0,450 & $-0,377$ & 1,000 & \\
\hline$M M P 9$ & $-0,178$ & $-0,095$ & $-0,278$ & $-0,175$ & $-0,001$ & 0,371 & $-0,205$ & 0,354 & 1,000 \\
\hline NKX3-1 & 0,817 & 0,167 & 0,540 & 0,538 & $-0,199$ & $-0,514$ & 0,603 & $-0,453$ & $-0,304$ \\
\hline$P C A 3$ & 0,483 & $-0,429$ & 0,151 & 0,380 & $-0,224$ & $-0,299$ & 0,512 & $-0,651$ & $-0,269$ \\
\hline$P S A$ & 0,528 & $-0,363$ & 0,346 & 0,304 & $-0,560$ & $-0,316$ & 0,479 & $-0,446$ & $-0,354$ \\
\hline KRT18 & 0,402 & $-0,529$ & $-0,064$ & 0,103 & $-0,724$ & $-0,238$ & 0,363 & $-0,447$ & 0,017 \\
\hline MKI67 & 0,227 & 0,110 & 0,356 & 0,430 & $-0,127$ & $-0,275$ & 0,467 & 0,013 & $-0,016$ \\
\hline CASP3 & 0,250 & 0,568 & 0,492 & 0,389 & 0,485 & $-0,166$ & 0,443 & 0,012 & $-0,330$ \\
\hline$X I A P$ & 0,381 & 0,408 & 0,572 & 0,524 & 0,238 & $-0,283$ & 0,654 & $-0,197$ & $-0,308$ \\
\hline PTEN & 0,015 & 0,317 & 0,232 & 0,012 & 0,263 & 0,287 & $-0,004$ & 0,497 & 0,231 \\
\hline HOTAIR & $-0,420$ & 0,552 & $-0,131$ & 0,062 & 0,561 & 0,090 & $-0,428$ & 0,206 & 0,122 \\
\hline SCHLAP1 & $-0,025$ & $-0,263$ & $-0,007$ & 0,127 & $-0,223$ & $-0,012$ & 0,356 & $-0,099$ & $-0,192$ \\
\hline
\end{tabular}


Table 6B (breakover)

\begin{tabular}{|l|r|r|r|r|r|r|r|r|r|r|}
\hline \multicolumn{1}{|c|}{ Genes } & NKX3-1 & \multicolumn{1}{c|}{ PCA3 } & \multicolumn{1}{c|}{ PSA } & KRT18 & MKI67 & CASP3 & XIAP & PTEN & HOTAIR & SCHLAP1 \\
\hline NKX3-1 & 1,000 & & & & & & & & & \\
PCA3 & 0,389 & & & & & & & & & \\
PSA & $\mathbf{0 , 4 8 3}$ & $\mathbf{0 , 6 6 0}$ & 1,000 & & & & & & & \\
KRT18 & 0,338 & $\mathbf{0 , 5 2 2}$ & $\mathbf{0 , 6 9 4}$ & 1,000 & & & & & & \\
MKI67 & $\mathbf{0 , 4 6 8}$ & 0,092 & 0,285 & 0,201 & 1,000 & & & & & \\
CASP3 & $\mathbf{0 , 4 4 4}$ & $-0,037$ & $-0,067$ & $-0,338$ & 0,320 & 1,000 & & & & \\
XIAP & $\mathbf{0 , 5 7 5}$ & 0,214 & 0,030 & $-0,151$ & 0,392 & $\mathbf{0 , 7 5 4}$ & 1,000 & & & \\
PTEN & 0,024 & $-\mathbf{0 , 4 2 8}$ & $-0,352$ & $-0,272$ & $-0,183$ & 0,118 & 0,114 & 1,000 & & \\
HOTAIR & $-0,253$ & $-0,310$ & $-\mathbf{0 , 5 3 2}$ & $-\mathbf{0 , 6 5 2}$ & $-0,171$ & $-0,003$ & $-0,031$ & 0,029 & 1,000 & \\
SCHLAP1 & $-0,019$ & 0,376 & $\mathbf{0 , 5 7 5}$ & $\mathbf{0 , 6 1 3}$ & 0,186 & $-0,016$ & $-0,071$ & $-0,334$ & $-0,422$ & 1,000 \\
\hline
\end{tabular}

Note: $\mathbf{p}<\mathbf{0 , 0 0 0 1}$ (bold type), $\boldsymbol{p}<\mathbf{0 , 0 1}$ (bold+italic type), $p<0,05$ (italic type) with FDR $=0,1$

of mesenchymal markers and decrease of epithelial marker expression is a feature of tumor progression, invasiveness and metastasizing, and this indicates, as a rule, the aggressiveness of tumor and poor disease prognosis [25].

Crucial changes in expression of the EMTrelated genes have been shown on different solid tumors and the cell line models. It is difficult, to investigate EMT on biopsies, because there are many types of cells in each tissue sample, that influence on the registered gene expression. Every tissue sample contains also normal epithelial cells, different types of immune cells, stromal components (fibroblasts, endothelial cells) etc. Therefore, an important task is to determine the gene expression pattern in the specific cell types, to understand the nature of changes.

Our results have shown that changes in RE changes of different genes are often heterogeneous, especially in prostate adenocarcinoma group. Probably, the ordinary grouping did not reflect the sample heterogeneity and also the stage, type, different factors of carcinogenesis and molecular characteristic of the types and subtypes of prostate cancer [2]. Differences in RE of more, than 10-20 folds in one group suggest that there are samples with both, low and high expression levels, as also unaltered one. To understand the nature of these variations, it is necessary to determine the causal carcinogenic factors and molecular processes.

We accomplish k-Means clustering of prostate adenocarcinomas RE for all 19 genes to search characteristic RE profiles for prostate cancer subtyping. It is possible to divide this adenocarcinoma group from 2 to 4 clusters, but the best number of clusters is two (using all 19 investigated genes as an example) (Figure 2). Cluster 1 has 20 adenocarcinoma samples (54\%). Cluster 2 has 17 adenocarcinoma samples (46\%).

All genes in two clusters could be sorted into three groups, according to their RE levels: 1) high RE in cluster 1 (these genes are potential markers of cluster 1); 2) high RE in cluster 2 (these genes are potential markers of cluster 2); 3) without changes in both clusters. 
Clusterization data well agree with Spearman correlations.

Genes in cluster 1 that are highly expressed, are epithelial markers $(C D H 1, O C L N$,$) and$ prostate luminal cell markers $(A R(1$ isof), KRT18, NKX3-1, PSA). Strong expression of these genes is typical for the luminal subtype of tumors [26, 27]. In addition, cluster 1 showed high RE of two lncRNA (PCA3 and $S C H L A P 1)$. PCA3 is very high specific lncRNA in prostate cancer cells [28]. SCHLAP1 is associated with metastatic progression in prostate cancer [29].

Moreover, high RE of $A R$ ( 2 isof) in cluster 1 , which is tissue specific variant (named $A R 45$ ) and extrinsic for normal prostate, is very important for modulation of AR function especially in the presence of adrenal androgens [30].

The opposite situation of RE levels is in cluster 2. Here the low expression of epithelial cells markers was observed, and high expression of mesenchymal markers $(\mathrm{CDH} 2$, FN1, VIM). This is typical for the basal subtype of prostate cancer, on the one hand [27, $31]$. On the other hand, it is also characteristic for cancer stem cells [31]. Besides, the high
RE of HOTAIR is also detected, and HOTAIR is the specific lncRNA of cancer stem-like cell subpopulation [30].

We suppose, that prostate cancer samples from different clusters could be a subjects of different oncogenic pathways, carcinogenic mechanisms and, as a result, they could have different drug sensitivity and prognosis [27].

Prostate cancers were sub-grouped in from 3 to 7 subtypes, according to as transcriptome changes [27,31], based on genetic, epigenetic and transcriptome alterations of hundreds of genes [32]. Therefore, to propose a molecular signature of cancer subtypes, we shall investigate and characterize the specific changes of RE levels further.

\section{Conclusions}

Investigation of RE of the 19 EMT-related genes in benign and malignant prostate tumors has shown the 9 differentially expressed genes, namely $A R(1$ isof), $A R(2$ isof), PTEN, VIM, MMP9, KRT18, PCA3, HOTAIR, and SCHLAP1.

Interestingly, RE patterns were similar in the conventionally normal tissue group and the corresponding adenocarcinoma groups. This

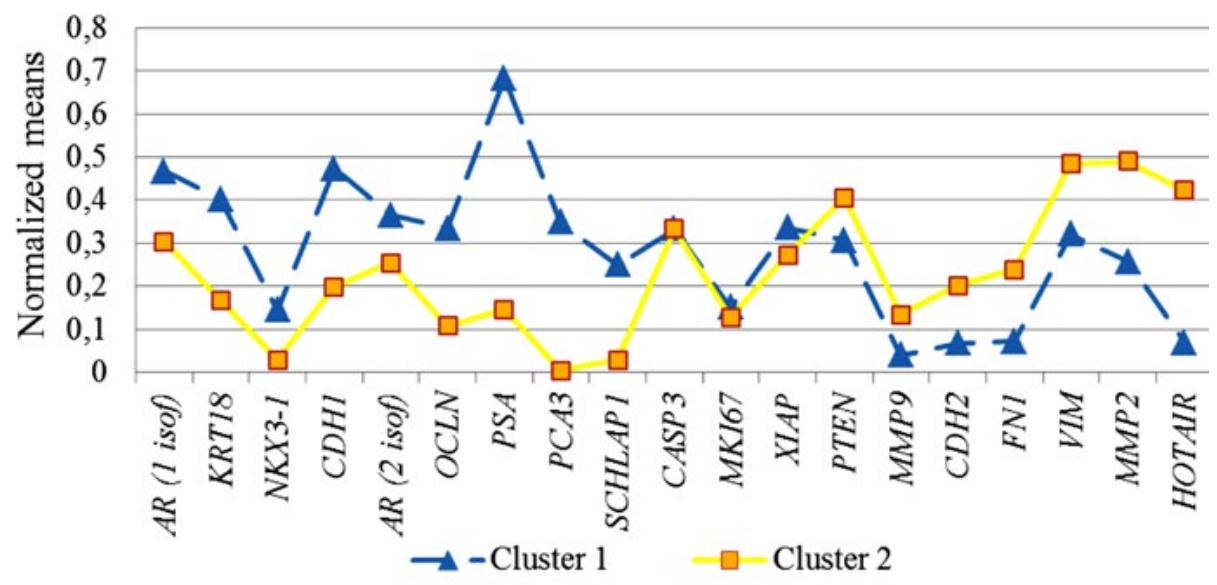

Fig. 2. Normalized RE profiles of 19 genes, divided into two clusters by k-Means clustering. 
means that these conventionally normal tissues contained tumor cells and could not serve as an adequate control.

RE values of all investigated genes showed high levels of heterogeneity, especially in the prostate adenocarcinoma group. Presence of at least two different molecular subtypes of prostate adenocarcinoma may explain a high dispersion in RE levels of the EMT-related genes. The first is a luminal subtype with high expression of epithelial and luminal markers and two lncRNA (PCA3 and SCHLAP1), and the second is a stem-like subtype with low expression of luminal and high expression of mesenchymal markers and high expression of lncRNA HOTAIR. The further experiments are needed to confirm these findings.

\section{REFERENCES}

1. Nguyen T, Boldt RG, Rodrigues $G$. Prognostic factors for prostate cancer endpoints following biochemical failure: a review of the literature. Cureus. 2015; 7(1):e238.

2. Gerlinger $M$, Catto JW, Orntoft TF, Real FX, $Z$ warthoff $E C$, Swanton $C$. Intratumour heterogeneity in urologic cancers: from molecular evidence to clinical implications. Eur Urol. 2015;67(4):729-37.

3. Tomaskovic-Crook E, Thompson EW, Thiery JP. Epithelial to mesenchymal transition and breast cancer. Breast Cancer Res. 2009;11(6):213.

4. Thiery JP. Epithelial-mesenchymal transitions in tumour progression. Nat Rev Cancer. 2002;2(6):442-54.

5. Chappell WH, Abrams SL, Lertpiriyapong $K$, Fitzgerald TL, Martelli AM, Cocco L, Rakus D, Gizak A, Terrian D, Steelman LS, McCubrey JA. Novel roles of androgen receptor, epidermal growth factor receptor, TP53, regulatory RNAs, NFkappa-B, chromosomal translocations, neutrophil associated gelatinase, and matrix metalloproteinase-9 in prostate cancer and prostate cancer stem cells. Adv Biol Regul. 2016;60:64-87.
6. Song H, Zhang B, Watson MA, Humphrey PA, Lim H, Milbrandt $J$. Loss of Nkx3.1 leads to the activation of discrete downstream target genes during prostate tumorigenesis. Oncogene. 2009; 28(37):3307-19.

7. Pećina-Slaus $N$. Tumor suppressor gene E-cadherin and its role in normal and malignant cells. Cancer Cell Int. 2003;3(1):17.

8. Martin TA, Mansel RE, Jiang WG. Loss of occludin leads to the progression of human breast cancer. Int J Mol Med. 2010;26(5):723-34.

9. Niknami Z, Eslamifar A, Emamirazavi A, Ebrahimi A, Shirkoohi $R$. The association of vimentin and fibronectin gene expression with epithelial-mesenchymal transition and tumor malignancy in colorectal carcinoma. EXCLI J. 2017;16:1009-1017.

10. Zhong WD, Han ZD, He HC, Bi XC, Dai QS, Zhu G, Ye YK, Liang YX, Qin WJ, Zhang Z, Zeng GH, Chen ZN. CD147, MMP-1, MMP-2 and MMP-9 protein expression as significant prognostic factors in human prostate cancer. Oncology. 2008;75(34):230-6.

11. Zhu ML, Kyprianou N. Role of androgens and the androgen receptor in epithelial-mesenchymal transition and invasion of prostate cancer cells. FASEB J. 2010;24(3):769-77.

12. Prensner JR, Rubin MA, Wei JT, Chinnaiyan AM. Beyond PSA: the next generation of prostate cancer biomarkers. Sci Transl Med. 2012;4(127):127rv3.

13. Fortier AM, Asselin E, Cadrin M. Keratin 8 and 18 loss in epithelial cancer cells increases collective cell migration and cisplatin sensitivity through claudin1 up-regulation. J Biol Chem. 2013;288(16): 11555-71.

14. Ha SA, Lee YS, Kim HK, Yoo J, Kim S, Gong GH, Lee YK, Kim JW. The prognostic potential of keratin 18 in breast cancer associated with tumor dedifferentiation, and the loss of estrogen and progesterone receptors. Cancer Biomark. 2011;10(5):219-31.

15. Tretiakova MS, Wei W, Boyer HD, Newcomb LF, Hawley S, Auman H, Vakar-Lopez F, McKenney JK, Fazli L, Simko J, Troyer DA, Hurtado-Coll A, Thompson IM Jr, Carroll PR, Ellis WJ, Gleave ME, Nelson PS, Lin DW, True LD, Feng Z, Brooks JD. Prognostic value of Ki67 in localized prostate carcinoma: a multi-institutional study of $>1000$ 
prostatectomies. Prostate Cancer Prostatic Dis. 2016;19(3):264-70.

16. O'Donovan $N$, Crown J, Stunell H, Hill AD, McDermott E, O'Higgins N, Duffy MJ. Caspase 3 in breast cancer. Clin Cancer Res. 2003;9(2):738-42.

17. Jäger $R$, Zwacka RM. The enigmatic roles of caspases in tumor development. Cancer (Basel)s. 2010; 2(4):1952-1979.

18. Obexer P, Ausserlechner MJ. X-linked inhibitor of apoptosis protein - a critical death resistance regulator and therapeutic target for personalized cancer therapy. Front Oncol. 2014;4:197.

19. Lemos AE, Ferreira LB, Batoreu NM, de Freitas PP, Bonamino MH, Gimba ER. PCA3 long noncoding RNA modulates the expression of key cancer-related genes in LNCaP prostate cancer cells. Tumour Biol. 2016;37(8):11339-48.

20. Hajjari M, Salavaty A. HOTAIR: an oncogenic long non-coding RNA in different cancers. Cancer Biol Med. 2015; 12(1):1-9.

21. Prensner JR, Iyer MK, Sahu A, Asangani IA, Cao Q, Patel L, Vergara IA, Davicioni E, Erho N, Ghadessi M, Jenkins RB, Triche TJ, Malik R, Bedenis R, McGregor N, Ma T, Chen W, Han S, Jing X, Cao X, Wang X, Chandler B, Yan W, Siddiqui J, Kunju LP, Dhanasekaran SM, Pienta KJ, Feng FY, Chinnaiyan $A M$. The long noncoding RNA SChLAP1 promotes aggressive prostate cancer and antagonizes the SWI/SNF complex. Nat Genet. 2013;45(11): 1392-8.

22. Schmidt U, Fuessel $S$, Koch R, Baretton GB, Lohse A, Tomasetti $S$, Unversucht $S$, Froehner $M$, Wirth MP, Meye A. Quantitative multi-gene expression profiling of primary prostate cancer. Prostate. 2006;66(14):1521-34.

23. Livak KJ, Schmittgen TD. Analysis of relative gene expression data using real-time quantitative PCR and the 2(-Delta Delta C(T)) Method. Methods. 2001;25(4):402-8.

24. Benjamini Y, Hochberg Y. Controlling the false discovery rate: a practical and powerful approach to multiple testing. J R Stat Soc Series B Stat Methodol. 1995, 57(1): 289-300.

25. Montanari M, Rossetti S, Cavaliere C, D'Aniello C, Malzone MG, Vanacore D, Di Franco R, La Mant- ia E, Iovane G, Piscitelli R, Muscariello R, Berretta M, Perdonà S, Muto P, Botti G, Bianchi AAM, Veneziani BM, Facchini G. Epithelial-mesenchymal transition in prostate cancer: an overview. Oncotarget. 2017;8(21):35376-35389.

26. Zhao SG, Chang SL, Erho N, Yu M, Lehrer J, Alshalalfa M, Speers C, Cooperberg MR, Kim W, Ryan CJ, Den RB, Freedland SJ, Posadas E, Sandler H, Klein EA, Black P, Seiler R, Tomlins $S A$, Chinnaiyan AM, Jenkins RB, Davicioni E, Ross AE, Schaeffer EM, Nguyen PL, Carroll PR, Karnes RJ, Spratt DE, Feng FY. Associations of luminal and basal subtyping of prostate cancer with prognosis and response to androgen deprivation therapy. JAMA Oncol. 2017;3(12): 16631672.

27. Park JW, Lee JK, Phillips JW, Huang P, Cheng D, Huang J, Witte ON. Prostate epithelial cell of origin determines cancer differentiation state in an organoid transformation assay. Proc Natl Acad Sci U S A. 2016;113(16):4482-7.

28. Yang Z, Yu L, Wang Z. PCA3 and TMPRSS2-ERG gene fusions as diagnostic biomarkers for prostate cancer. Chin J Cancer Res. 2016;28(1):65-71.

29. Prensner JR, Zhao S, Erho N, Schipper M, Iyer MK, Dhanasekaran SM, Magi-Galluzzi C, Mehra R, Sahu A, Siddiqui J, Davicioni E, Den RB, Dicker AP, Karnes RJ, Wei JT, Klein EA, Jenkins RB, Chinnaiyan $A M$, Feng $F Y$. RNA biomarkers associated with metastatic progression in prostate cancer: a multiinstitutional high-throughput analysis of SChLAP1. Lancet Oncol. 2014;15(13):1469-80.

30. Ahrens-Fath I, Politz O, Geserick C, Haendler B. Androgen receptor function is modulated by the tissue-specific AR45 variant. FEBS J. 2005;272(1): 74-84.

31. Smith BA, Sokolov A, Uzunangelov V, Baertsch R, Newton Y, Graim K, Mathis C, Cheng D, Stuart JM, Witte $O N$. A basal stem cell signature identifies aggressive prostate cancer phenotypes. Proc Natl Acad Sci U S A. 2015;112(47):E6544-52.

32. Deng J, Yang $M$, Jiang $R$, An $N$, Wang $X$, Liu $B$. Long Non-Coding RNA HOTAIR regulates the proliferation, self-renewal capacity, tumor formation and migration of the cancer stem-like cell (csc) 
subpopulation enriched from breast cancer cells. PLoS One. 2017;12(1):e0170860.

33. Cancer Genome Atlas Research Network. The molecular taxonomy of primary prostate cancer. Cell. 2015;163(4):1011-25.

\section{Експресія генів, пов'язаних 3 епітеліально- мезенхімальним переходом у пухлинах передміхурової залози}

Г. В. Геращенко, О. С. Маньковська, О. О. Дмітрієв, Л. В. Мевс, Є. Е. Розенберг, М. В. Пікуль, М. В. Мариниченко, О. П. Гризодуб, Е. О. Стаховський, В. І. Кашуба

Мета: встановити відносну експресію у ЕМПпов'язаних генах у зразках пухлин передміхурової залози та проаналізувати можливу кореляцію та зв'язок між рівнем експресії генів у різних групах пухлин та клінічними характеристиками раку передміхурової залози. Методи: Відносні рівні експресії 19 генів у 37 заморожених зразках тканин раку передміхурової залози з різними показниками Глісона та стадіями пухлин, 37 парних умовно-нормальних зразків тканини передміхурової залози та 20 зразків аденоми простати було детектовано кількісною ПЛР (QPCR). Результати: Було виявлено 9 диференційно експресованих генів у доброякісних та злоякісних пухлинах простати: (AR (1 isof), AR (2 isof), PTEN, VIM, MMP9, KRT18, PCA3, HOTAIR, SCHLAP1). На різних стадіях раку виявлено 6 диференційно експресованих генів (KRT18, MMP9, VIM, PCA3, HOTAIR, SCHLAP1), а за різними оцінками Глісона виявлено 8 диференційно експресованих генів (AR (1 isof), CDH1, KRT18, MMP9, OCLN, PCA3, HOTAIR, SCHLAP1). Спостерігався значний рівень дисперсії даних. Це можна пояснити наявністю різних молекулярних підтипів раку передміхурової залози: люмінальний підтип (висока експресія CDH1, OCLN, AR (1 isof), KRT18, NKX3-1, PSA) і стовбуровий (базальний) підтип (висока експресія мезенхимальних маркерів $C D H 2, F N 1$, VIM і низька експресія епітеліальних маркерів). Досліджені некодуючі РНК були специфічно експресованіі у двох молекулярних підтипах. Висновки: пов'язані з ЕМП гени диференційно експресуються у доброякісних та злоякісних пухлинах передміхурової залози. Висока дисперсія даних експресії, особливо в групах аденокарциноми, може бути свідченням принаймні двох різних молекулярних підтипів: люмінального і стовбурового (базального). Нами продемонструвано, що умовно-нормальні тканини передміхурової залози не є адекватним контролем. Для уточнення молекулярних підтипів аденокарциноми передміхурової залози необхідні додаткові дослідження.

К л ю ч о в і с л о в а: пухлини передміхурової залози, ЕМП, відносна експресія генів, молекулярні підтипи, некодуючі РНК.

\section{Экспрессия генов, связанных с эпителиально- мезенхимальным переходом в опухолях простаты}

А. В. Геращенко, О. С. Маньковская, А. А. Дмитриев, Л. В. Мевс, Е. Э. Розенберг, М. В. Пикуль, М. В. Мариниченко, А. П. Гризодуб, Э. А. Стаховский, В. И. Кашуба

Цель: Установить уровни относительной экспрессии генов, связанных с ЭМП, в образцах опухолей предстательной железы и проанализировать возможную корреляцию и взаимосвязь между уровнем экспрессии генов в разных группах опухолей и клиническими характеристиками рака простаты. Методы: Относительные уровни экспрессии 19 генов в 37 замороженных образцах тканей рака предстательной железы с разными показателями Глисона и стадиями рака, 37 парных образцов условно-нормальной ткани простаты и 20 образцов аденомы предстательной железы были проанализированы с помощью количественной ПЦР (QPCR). Результаты: Было выявлено 9 дифференциально экспрессированных генов в доброкачественных и злокачественных опухолях предстательной железы: (AR (1 isof), AR (2 isof), PTEN, VIM, MMP9, KRT18, PCA3, HOTAIR, SCHLAP1). На разных стадиях рака были идентифицированы 6 дифференциально экспрессированных генов (KRT18, MMP9, VIM, PCA3, HOTAIR, SCHLAP1), тогда как с разными показателями по шкале Глисона было найдено 8 дифференциально экспрессированных генов (AR (1isof), CDH1, KRT18, MMP9, OCLN, PCA3, HOTAIR, SCHLAP1). Наблюдалась очень высокая дисперсия данных. Это может быть объяснено наличием различных молекулярных подти- 
пов рака предстательной железы: люминального подтипа (высокая экспрессия CDH1, OCLN, AR (1 изоф), $K R T 18, N K X 3-1, P S A)$ и стволового (базального) подтипа (высокая экспрессия мезенхимальных маркеров $C D H 2, F N 1, V I M$ и низкая экспрессия эпителиальных маркеров). Исследованные некодирующие РНК специфически экспрессировались в двух молекулярных подтипах. Выводы: Гены, связанные с ЭМП, были дифференциально экспрессированы в доброкачественных и злокачественных опухолях предстательной железы. Высокая дисперсия данных экспрессии, особенно в группе аденокарцином, может свидетельствовать, по меньшей мере, о двух разных молекулярных подтипах: люминальном и базальном. Мы продемонстрировали, что условно-нормальные ткани простаты не являются адекватным контролем. Для уточнения молекулярных подтипов аденокарциномы предстательной железы необходимы дополнительные исследования.

Ключе вы е сл ов а: опухоли предстательной железы, ЭМП, относительная экспрессия генов, молекулярные подтипы, некодирующие РНК.

Received 25.08.2017 